\title{
Playground Safety Practices. Injury Prevention and Effective Investigation
}

\author{
Alexandra Ioana Curcă \\ "Dimitrie Cantemir" Christian University of Bucharest, Bucharest, Romania, allecsis@yahoo.com
}

\begin{abstract}
While technology and business patterns are evolving at a very high pace, new markets are developing, and so are consumer preferences and expectations. Over the past 30 years, entertainment industries have become sectors with immense profits and sustainable growth, the children segment being the greatest contender. However, the multitude of options in terms of attractions to choose from is not always accompanied by strict knowledge of operational standards, thus creating an increase in the risk of injury that children are subjected to during their play-time. Despite the fact that most playground equipment's are not properly certified or do not comply with the specific provisions, most cases remain inconclusive, due to lack of evidence arising from a knowledge gap that the authorities must cover. In case of playground accidents, the investigators need to be well aware and up to date with the regulations, not only to determine who to hold accountable, but also to be able to take the necessary control measures in order to reduce children playrelated injuries.
\end{abstract}

KEYWORDS: accident, children, injuries, playground, safety

\section{Introduction}

The entertainment sector has been facing a perpetual transformation for the past decade, rapidly improving and developing the multitude of solutions made available to the consumer looking for diversity.

As far as children are concerned, this variety comes along with a number of reasons that prevail in the decisions of their parents or caretakers when they choose a form of entertainment on their behalf. By all means, the safety factor should always be a top priority.

Apart from all the benefits that playgrounds bring to the harmonious growth of our youth, they represent also the most frequent settings for accidents in case of those below 14 years of age, due to them being highly exposed to these types of locations they get in contact with - at schools, in parks, commercial centers, etc.

The most common circumstances in which related accidents occur are either falls from equipments, or injuries caused by moving elements and many times even physical contact between two or more kids.

But some factors causing these occurrences are determined by the nonobservance of legal provisions regarding the proper functioning of equipments, or the absence of information on the risks in usage.

\section{Aspects concerning children playgrounds in public spaces (outdoor playgrounds)}

The outdoor environment is the perfect place for children to put their energy to good use through activities such as running, jumping, sliding or pushing a swing; but many existing playgrounds should be removed and replaced, because children are not safe among rusty or weakened material that have not been improved or properly maintained.

However, the modernization tendency of recent years has brought forth a different perspective on the manner in which equipments are manufactured. If metal was used as predominant material, nowadays plastic, wood and rubber prevail, while the industrial pattern is constantly adapted and oriented towards improving children safety during playtime.

\section{Aspects concerning children playgrounds in shopping centers (indoor playgrounds)}

All entertainment demands in commercial spaces are currently met at maximum capacity. In every shopping mall, potential clients or visitors are also parents, who bring their younger ones to the existing 
playgrounds and they hand over their care to trained employees upon payment of an entrance fee, while they continue their shopping activities.

The presented types of playgrounds are thus distinguished not only by the operational manner that they function in, but also by how the criminal liability is expanding from the administrator of the space, to those who are assigned supervision duties.

Nevertheless, all those responsible need to prevent any risk of injuries caused by accidents, through an in-depth knowledge of the risks in usage that each equipment might face and to avoid overcrowding in order to ensure that the play activities are carried out in complete safety.

On the other hand, failing to perform these tasks is not considered negligence in every circumstance, since it is neither necessary nor possible to supervise a particular child throughout the entire duration of his playtime. A supervisor might have within his range a slightly higher than average number of children that he cannot practically watch simultaneously over, especially since they can slip into smaller areas that full grown individuals cannot access, as most equipments restrict their use by people who pass a certain weight or height limit.

\section{European safety standards}

Due to the fact that they set the general safety requirements for playground equipments while considering the risk factor based on the available data, these standards described below have been adopted as local standards and apply to both outdoor and indoor equipments (but not to amusement parks that are part of an entirely different risk classification).

Their purpose is to prevent accidents with major or fatal complications, and at the same time to diminish the occasional consequences that will inevitably arise from children's focus on expanding their level of proficiency.

All these related play attractions have been defined as recreational equipments, exclusively operated by human weight or physical strength, intended for children's use, on a temporary or permanent playground (H.G. no 435/ 2010, Art. 2).

EN 1176 - Playground equipment and surfacing - is presented in 9 parts, as follows:

- EN 1176-1. General safety requirements and test methods (ASRO, SR EN 1176-1, 2009, 27).

This part provides information applicable to all the types of equipments falling under the standard.

Materials must meet certain requirements, be of superior quality and have protective covering in certain areas; proper structural integrity must be proven so that the construction is manufactured in optimum conditions and withstand the most unfavorable physical demands.

Various measures against material locking must be taken, as well as for remaining openings in the design of the equipments, so as not to risk blocking certain parts of the body while using the items, and specific calculations must be made for determining the impact zones and the minimum spaces of all these devices. 


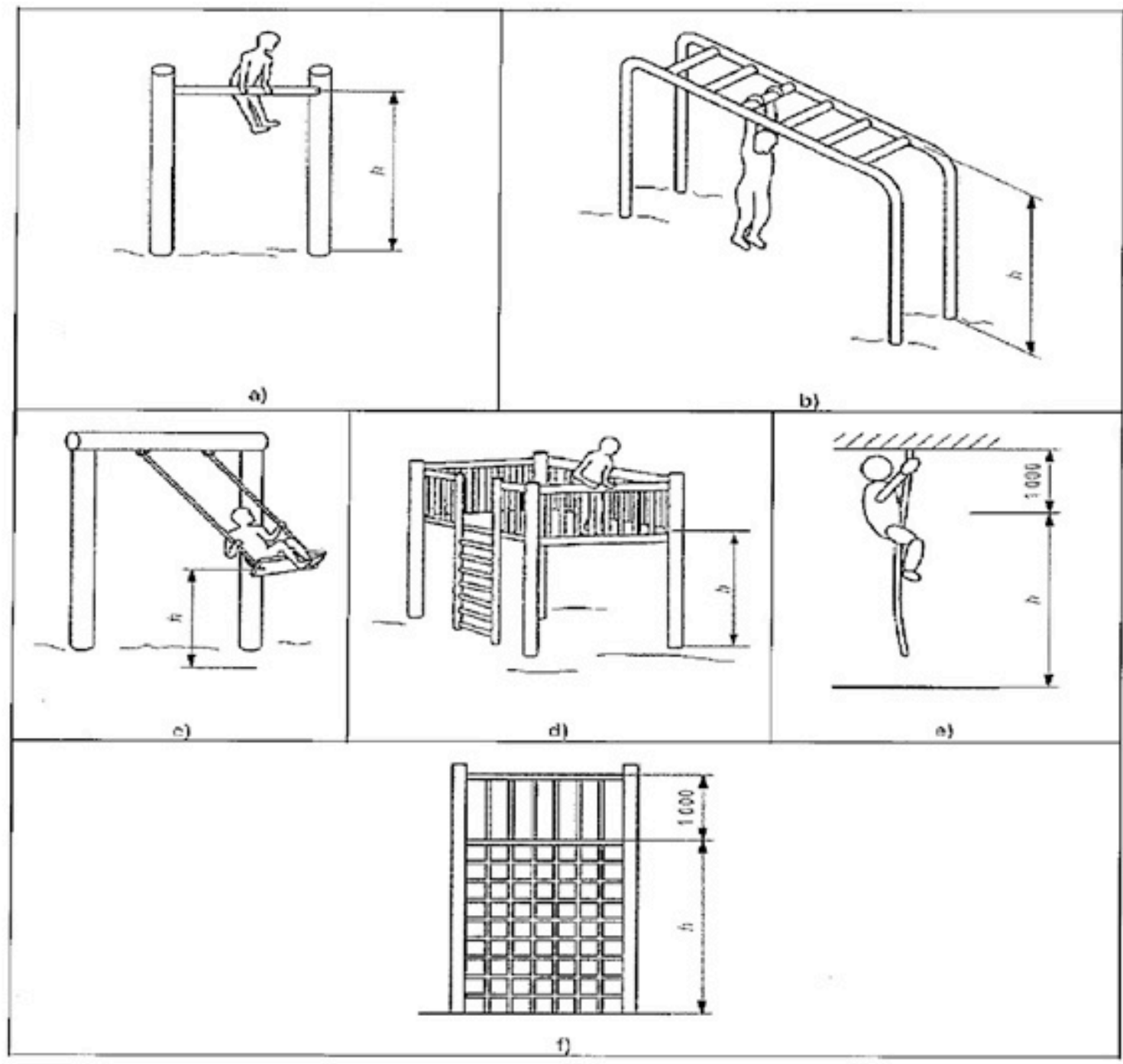

Figure 1. Examples of heights in free fall

Surce: ASRO, SR EN 1176-1, 2009, 27

- EN 1176-2. Additional specific safety requirements and test methods for swings (ASRO, SR EN 1176-2, 2010).

This part of EN 1176 focuses on the additional safety requirements related specifically to swings, with their definition and examples of models, while providing information on free safety spaces from the ground or for the seat position, on stability, frames, suspension points, and so forth.

- EN 1176-3. Additional specific safety requirements and test methods for slides (ASRO, SR EN 1176-3, 2010).

Much like the part before it, this one also indicates further safety requirements related just to slides that are permanently installed, and does not apply to the types requiring the use of auxiliary equipments or that are installed on other kinds of surfaces (water or uphill).

An essential reference for this specific device, which also became an imperative in the local legislation - through Government Decision no. 435/2010 in Annex 1 at Article 14 - Essential safety requirements - is the prohibition of the use of metallic materials in the manufacturing of sliding surfaces.

- EN 1176-4. Additional specific safety requirements and test methods for cableways (ASRO, SR EN 1176-4, 2008).

In this case, the provisions apply to transportation used by children to move along a cable, under the force of gravity. 
- EN 1176-5. Additional specific safety requirements and test methods for carousels (ASRO, SR EN 1176-5, 2009).

This situation raises the conditions for carousels having a diameter of more than $500 \mathrm{~mm}$ and do not apply to equipments that do not have rotation as primary function, or that are set in motion by an engine. These particular carousels have separate restrictions on heights and fall areas, impact areas, rotational speed for each type of defined item.

- EN 1176-6. Additional specific safety requirements and test methods for rocking equipment (ASRO, SR EN 1176-6, 2009).

The applicability is limited to seesaws or other types of related elements, that can be set in motion by their user and are generally defined by a rigid component that balances around a central support.

- EN 1176-7. Guidance on installation, inspection, maintenance and operation (ASRO, SR EN 1176-7, 2008).

The essential guidelines of this segment are the information on installation, control, maintenance and adequate operation of playground equipments, including auxiliary elements (gates, fences and other surfaces). Recommendations are also established on the inspections to be carried out in accordance with the manufacturer's generic and specific indications in order to preserve the safety of the play space.

- EN 1176-10. Additional specific safety requirements and test methods for fully enclosed play equipment (ASRO, SR EN 1176-10, 2008).

These enclosed play equipments are actually in or outside buildings with a separate entry and exit zone; guidance on escape routes is provided, as well as on accessibility for adults to assist children, visibility, fall and impact areas.

- EN 1176-11. Additional specific safety requirements and test methods for spatial network (used strictly for play and not for training purposes in sports activities) (ASRO, SR EN 1176-11, 2010).

In addition to all of these parts of standard EN 1176, which provides all general safety requirements for the defined play equipments, there is yet another essential factor in the injury risk mitigation, namely the importance of the materials to be used for all the impact areas, determined by the standard: EN 1177:2008. Impact attenuating playground surfacing - Methods of test for determination of impact attenuation.

In the configuration of an accident, there are a multitude of events and facts that contain various information coming from either the parties involved or witnesses, or arising from hard evidence such as the actual injuries, the final positions of the equipments, the type and size of damages, the placement of parts and loose objects.

Even if the most common cause of accidents is the fault of the users in the operation of the play equipments, in the rest of the situations, these causes can be divided into two main categories: technical and organizational issues. In the event of malfunction, the causes may also be a consequence of premeditated actions.

Technical issues are usually caused by the faulty performance or premature wear and tear of the equipments, inadequate quality of materials, technical maintenance procedures not being performed as per manufacturer's instructions, while the organizational ones are caused by the lack of appropriate security measures, negligence in the supervision process (in the case of employees from indoor playgrounds) and in the equipments operation and failure to meet the technical regulations.

Any conclusion about guilt should consider whether all the physical evidence can accurately indicate the circumstances of the accident, especially if all measures regarding the safety of the playground and the compliance of the equipments with the standards in force have been observed.

The situation at the scene of an accident is dynamic, sometimes rapidly changing, and evidence must be protected so as not to be destroyed or altered (Ionescu 2007, p. 28). Therefore, the investigator must promptly apply effective measures not only to preserve the evidence, but also to 
prevent the occurence of other similar incidents. The use of all equipments involved shall be restricted until the investigation is concluded and all deficiencies are remedied (Buzatu 2013, 27).

\section{Conclusions}

Over the past 30 years, entertainment industries have become sectors with immense profits and sustainable growth, the children segment being the greatest contender. However, the multitude of options in terms of attractions to choose from is not always accompanied by strict knowledge of operational standards, thus creating an increase in the risk of injury that children are subjected to during their play time.

Following a playground accident, it is essential to carry out a thorough investigation to determine the circumstance and cause of the injury and it may also involve an expert report, especially if there is a concern that the malfunction of the equipment or the playing surface has contributed to the event.

Acts of negligence that may result in accidents:

- Inappropriate maintenance of equipments and surfaces;

- Faulty equipment installation or unauthorized spare parts replacement - in conflict with the manufacturer's instructions; any new piece must comply with the same quality specifications as it was manufactured by, without compromising it by purchasing something similar but not appropriate, solely for budgetary reasons;

- The lack of instructions or poorly provided information on the risks that the children are subject to while using any equipment. If there are any restrictions in use, they must be displayed correctly for everyone to access.

- Deficient supervision during playtime - whether it is in a shopping mall where this responsibility is of a trained staff, or it is in an outdoor playground where the guardian must acknowledge all these potential risks and prevent such incidents.

Risk-taking is a major feature of the provisions and settings in which children spend their time playing. The developmental importance of play and risk is part of a controlled and stimulating learning environment, which should also tend towards a balance between the need to predict risks and the need to protect children from serious injuries.

Despite the fact that most playground equipments are not properly certified or do not comply with the specific requirements, most incidents remain inconclusive, due to lack of evidence arising from a knowledge gap that the authorities must cover. In case of playground accidents, the investigators need to be well aware and up to date with the regulations, not only to determine who to hold accountable, but also to be able to take the necessary control measures in order to reduce children play-related injuries and implement effective prevention strategies.

\section{References}

Buzatu, Nicoleta-Elena. 2013. Forensic Science (Criminalistică). Bucharest: Pro Universitaria Publishing House.

H.G. nr. 435/ 28.04.2010 privind regimul de introducere pe piaţă şi de exploatare a echipamentelor pentru agrement, published in Official Gazzete no. 323/ 17.05.2010.

Ionescu, Lucian. 2007. Criminalistică. Bucharest: Pro Universitaria Publishing House.

The Romanian Standards Association (ASRO). 2008. SR EN 1176-10, Playground equipment, Part 10: Cerințe complementare de securitate și metode de încercare pentru echipamente de joacă $\hat{i n}$ totalitate închise, 2nd Edition.

The Romanian Standards Association (ASRO). 2008. SR EN 1176-4. Equipment and surfaces for playgrounds, Part 4: Cerințe de securitate specifice suplimentare și metode de încercare pentru mijloace de transport pe cablu, 2nd Edition.

The Romanian Standards Association (ASRO). 2008. SR EN 1176-7, Equipment and surfaces for playgrounds, Part 7: Ghid de instalare, de control, de întreținere și de utilizare, 2nd Edition.

The Romanian Standards Association (ASRO). 2009. SR EN 1176-1, Equipment and surfaces for playgrounds, Part 1: Cerințe generale de securitate și metode de încercare, 2nd Edition.

The Romanian Standards Association (ASRO). 2009. SR EN 1176-5, Equipment and surfaces for playgrounds, Part 5: Cerințe de securitate specifice și metode de încercare suplimentare pentru carusele, 2nd Edition.

The Romanian Standards Association (ASRO). 2009. SR EN 1176-6, Equipment and surfaces for playgrounds Part 6: Cerințe de securitate specifice și metode de încercare suplimentare pentru echipamente oscilante, 2nd Edition. 
The Romanian Standards Association (ASRO). 2010. SR EN 1176-11, Equipment and surfaces for playgrounds, Part 11: Cerințe complementare de securitate și metode de incercare pentru rețele tridimensionale, 2nd Edition.

The Romanian Standards Association (ASRO). 2010. SR EN 1176-2, Equipment and surfaces for playgrounds, 2nd Edition: Cerințe de securitate specifice suplimentare și metode de încercare pentru leagăne, 2nd Edition.

The Romanian Standards Association (ASRO). 2010. SR EN 1176-3, Equipment and surfaces for playgrounds, Part 3: Cerințe de securitate specifice suplimentare și metode de incercare pentru tobogane, 2nd Edition. 